\title{
COMPARISON OF THE INDUSTRY 4.0 CONCEPT IN SELECTED COUNTRIES IN THE PERIOD OF GLOBALIZATION

\author{
Martina Kováčiková ${ }^{1}$, Katarína Repková Štofková ${ }^{2}$
}

\begin{abstract}
Our society goes beyond the threshold of a new technological revolution, which will obviously affect the world economy, affect the life, work, communication of people and facilities. Significant features of the economy include the growth of market variability, the shortening of product lifecycles, the growth of global chain influences, but also the fact that current consumers demand products with individual solutions. Intelligent items, products, machines and devices will allow manufacturers to produce original products without increasing costs. Industry 4.0 or the fourth industrial revolution is the name for dramatic changes and their current entry into the industry. The bearer of these changes is product digitization, digitization and optimization of all business processes, including services. The period of globalization brings new challenges for businesses.

This contribution is focused on the characteristics of Industry 4.0, the tools used for the area in question, the advantages and disadvantages of Industry 4.0 and the Industry 4.0 initiative concept and the comparison of the concept with the Czech Republic and Germany. The Czech Republic is geographically and culturally close to Slovakia, while Germany is the leader in this area within the EU.
\end{abstract}

JEL Classification Numbers: D40, L20, O30; DOI: http://dx.doi.org/10.12955/cbup.v6.1165

Keywords: Industry 4.0, concept, period of globalization, new challenges, business

\section{Introduction}

Industry 4.0 includes the naming large-scale changes taking place currently in production.. Changes cause product digitization, digitization and business process optimization, including services. The Industry 4.0 concept penetrates not only into the manufacturing world of companies but also into the ordinary life of people (electronic books, e-shops, and smart homes). The essence of Industry 4.0 is the direct communication and collaboration of people, machines, devices, products, entire logistics systems, utilizing a numerous untapped and untreated sources of information for faster and better decision making, about the production process.

The aim of the paper is to broaden the knowledge base of the subject matter and to compare the current state as well as changes as the prerequisite of the implementation of Industry 4.0 concepts. Research emphasizes innovation as an essential part of sustainability and competitiveness, import and export shares within the EU based on market value and Industry 4.0 concepts developed in the Slovak Republic, the Czech Republic and the Federal Republic of Germany. This contribution also shows the possibilities of using the experience in selected countries for companies in Slovakia.

\section{Characteristics of the Industry 4.0 concept}

The Industry 4.0 concept was first mentioned in 2011 at the Hannover Messe trade fair (an event dedicated to industrial technologies) as "Industrie 4.0" in the initiative to improve German competitiveness in the manufacturing industry. The German government has launched this initiative with the idea of facing progress in developing countries such as China or India, and because Western countries have not been able to compete in production costs. The aim was to overcome them in industrial technology and to be able to individualize production (The Clever way to find a job, 2017).

The so-called Intelligent Factory - Smart Factory is considered to be the main advantage of Industry 4.0 and it helps to perform tasks for machines or people. The result is intelligent products that meet the individual customer needs at a favourable price. In real time, we can monitor the status of the device based on online information. From a technological point of view, objects and tools have a significant share of the intelligent factory concept (Vachálek, 2017; Balga, 2018; Onofrejová \& Šimšík, 2017; CGI, 2017). The concept is linked to some terms and uses solutions that are a prerequisite and are mentioned by the authors mentioned above. We can mention, for example:

- The Internet of Things is a network that consists of physical, uniquely identifiable objects. These objects have built-in electronics, software, sensors and network connectivity (CPS).

\footnotetext{
${ }^{1}$ Faculty of Operation and Economics of Transport and Communication, University of Žilina, martina.kovacikova@fpedas.uniza.sk

${ }^{2}$ Faculty of Operation and Economics of Transport and Communication, University of Žilina, katarina.stofkova@fpedas.uniza.sk
} 
- Business store, process, and make available big data for effective operation, decision making, risk reduction, and customer service.

- Cloud - resources are accessible to the user when they need them from anywhere and at any time via an Internet connection and are only available for the resources they use.

- Digital twin is a real-time physical collaboration system with its own digital "copy". It is designed to create a digital business environment where the information needed to shorten and streamline the production cycle, shorten the time of introducing new products, and uncover ineffective process setups is gathered and constantly evaluated.

- CPS cyber-physical systems are a combination of virtual and physical world. Systems consist of physical objects that are monitored and controlled by computer software and continually evaluated.

A competitive environment, economic crisis but also the political situation largely affects the business climate. In order to retain customers and achieve the maximum profit enterprises are pushed to implement innovative processes in their production (Štofko et al., 2015).

\section{Methodological background}

Industry 4.0 reflects the social change caused by connecting the physical, virtual and social world. This is a global change affecting industry, technical standardization, security, education, the legal framework, research, interconnection to social systems, the labour market and demands for workers, their education and specialization (Čierny, 2017).

Activities related to science, research and innovation can be considered as the driving force behind the economic growth of the countries and their competitiveness. These activities reflect, for example, the Summary Innovation Scoreboard. Innovation in industry is important for countries, especially in terms of import and export, which are heavily dependent on them to maintain their market position and reduce the competitive pressure of other countries.

Due to the scale of the issue, three countries have been selected to be compared. These are the Slovak Republic, the Czech Republic and Germany, of which Germany is considered to be the leader in the field of innovation but especially in Industry 4.0 within the EU.

\section{Comparison of selected countries for innovation, import and export}

\section{Innovations}

Innovation can be separated into four groups: product innovation, process innovation, organizational innovation and marketing innovation (OECD, 2005). These four innovation groups are further divided into technological and non-technological.

The innovation process is a multi-disciplinary tool that concentrates on new products development and their marketing and it is connected to the phase of commercialization and communication with customers as the subjects of the innovation process. (Loučanová et al., 2016)

Innovation is one of the major tools to promote business competitiveness and economic growth. In order to assess the level of innovation of individual countries, it is possible to use indexes: Summary Innovation Index, Innovation Index, National Innovation Capacity Index and others. The Summary Innovation Index was chosen for comparisons between the selected countries.

The Summary Innovation Index aims to provide an assessment of national innovation performance (Figure 1). It was created to measure innovation from the point of view of inputs and outputs. Within the input group, the index takes into account tertiary education, information and communication technologies (ICT), science and research and ICT expenditure, and business practices of small and medium-sized enterprises. The output group includes high-tech export, employment, sales of new products on the market, patents and trademarks. The index is part of the European Innovation Scoreboards, which has been compiled since 2001.

Based on the Summary Innovation Scoreboard, countries are divided into four groups - see Figure 1 . Import, export

Export and import also have a strong impact on national GDP. Innovations also affect to a certain extent the level of import and export of countries. Sustainable growth is important for maintaining the competitiveness of the economy (Table 1). 


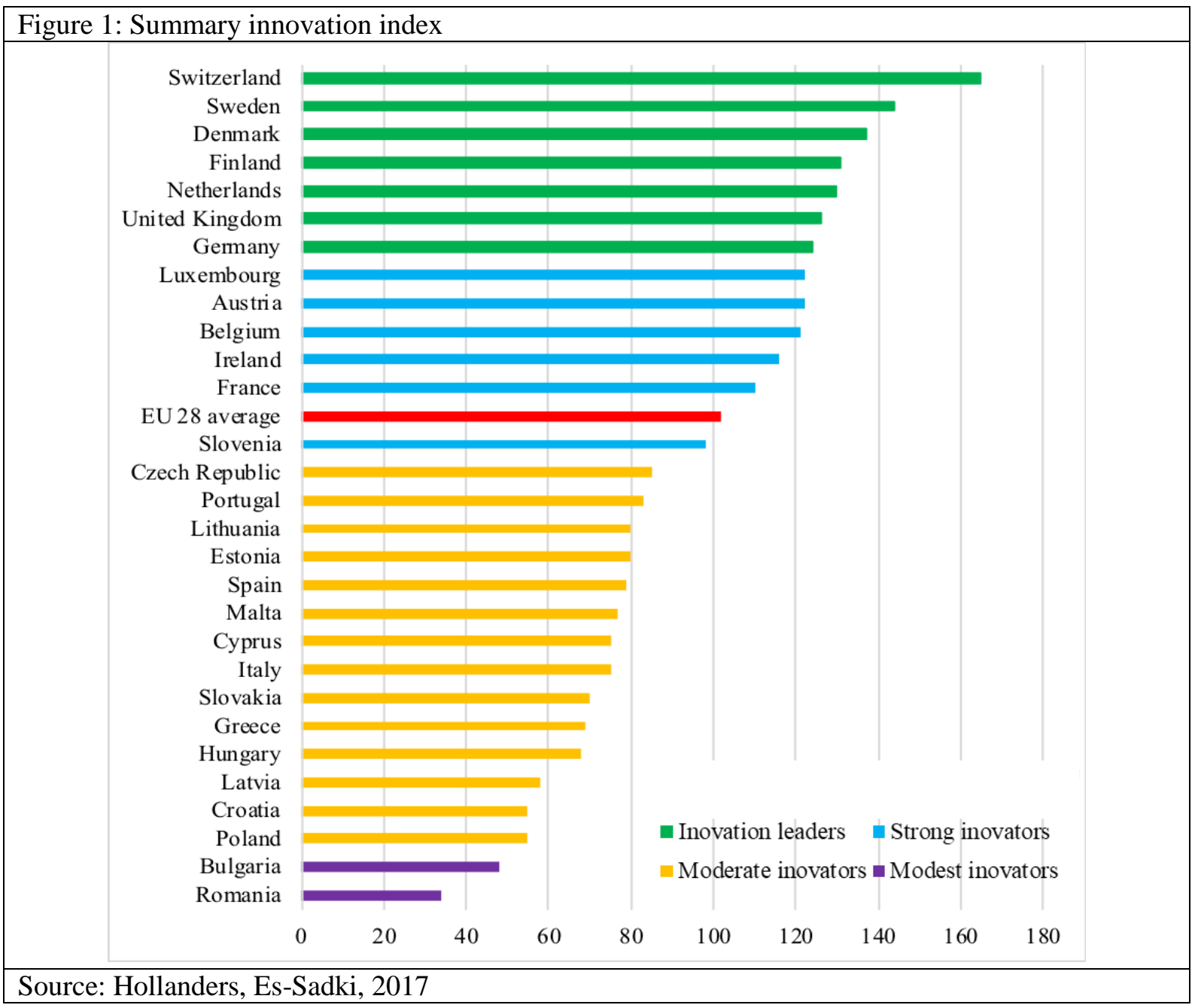

In Slovakia, industrial production dominates the economic sector. An important role is played by the competitiveness of Slovak production. Industrial production needs to be significantly upgraded in order to increase the recovery of materials and energy, which also involves more investment resources. Slovakia is considered to be an industrialized state in which the industry's share of the GDP was $34.84 \%$ in 2016, mainly due to the automotive industry (ME SR, 2017).

The Czech Republic belongs to the fastest growing economies within the European Union. An important role in the Czech economy is played by the industrial production, The Czech Republic has a very open economy, so it is necessary to monitor the development of industry in other countries. The Czech Republic is therefore the same as Slovakia in that it is dependent on the export of industrial goods abroad. The most important component of the export in 2016 was automobiles and their parts, electrical and industrial equipment, iron and steel, plastic products and furniture, the most traditional export product being glass, bijouterie and beer (MFEA SR, 2017a).

Germany is among the most advanced countries in the world, economically the most important state of Europe with a high standard of living. Germany is the strongest European economy and the fourth largest economy in the world. It is also the third largest exporter in the world and a key economic partner of Slovakia and the Czech Republic. Currently, the German economy recorded stable growth.

Germany, like Slovakia and the Czech Republic, is considered an industrial country where industry has a $30.4 \%$ share of the GDP. Germany's GDP accounts for more than $20 \%$ of the total GDP of the European Union. The most important branch of the German industrial economy is the engineering industry, which is one of the world powers, mainly thanks to automotive production (MFEA SR, 2017b; globalEDGE, 2017).

Slovakia is a country which, according to Eurostat (2016), is the most dependent on exports to other Member States, up to $85 \%$ of exports being directed to EU countries. Similarly, imports also account 
for up to $80 \%$ of imports coming from other EU Member States. Only Latvia (81\%) and Estonia $(82 \%)$ had higher imports.

Table 1: Export and import share within the EU, 2016 (based on market value), \%,

\begin{tabular}{|c|c|c|}
\hline Country & $\begin{array}{c}\text { Import share within the EU, 2016 } \\
\text { (based on market value), in\% }\end{array}$ & $\begin{array}{c}\text { Share of exports within the EU, 2016 } \\
\text { (based on market value), in\% }\end{array}$ \\
\hline Austria & 78 & 71 \\
\hline Belgium & 63 & 72 \\
\hline Bulgaria & 67 & 68 \\
\hline Croatia & 77 & 66 \\
\hline Cyprus & 74 & 46 \\
\hline Czech Republic & 79 & 84 \\
\hline Denmark & 71 & 62 \\
\hline Estonia & 82 & 74 \\
\hline EU & 64 & 63 \\
\hline Finland & 73 & 59 \\
\hline France & 69 & 59 \\
\hline Germany & 66 & 59 \\
\hline Greece & 55 & 56 \\
\hline Hungary & 78 & 81 \\
\hline Ireland & 68 & 51 \\
\hline Italy & 61 & 56 \\
\hline Latvia & 81 & 70 \\
\hline Lithuania & 70 & 61 \\
\hline Luxembourg & 77 & 83 \\
\hline Malta & 54 & 39 \\
\hline Netherlands & 47 & 76 \\
\hline Poland & 72 & 80 \\
\hline Portugal & 78 & 75 \\
\hline Romania & 77 & 75 \\
\hline Slovakia & 80 & 85 \\
\hline Slovenia & 71 & 75 \\
\hline Spain & 62 & 67 \\
\hline Sweden & 71 & 59 \\
\hline United Kingdom & 52 & 47 \\
\hline Source: own processing (by Europske noviny, 2017) & \\
\hline
\end{tabular}

The Czech Republic is the most dependent state from exports to the other EU Member States, right after Slovakia, where up to $84 \%$ of exports were to the EU Member States in 2016. Similarly, this is also the case with imports, with $79 \%$ of imports coming from other EU countries.

\section{Industry 4.0 concept in selected countries}

The Industry evolution, specifically Industry 4.0 is described through concepts of the selected countries - Slovakia, the Czech Republic and Germany. Industrial production is the dominant sector in the overall economy of the selected countries, and therefore the implementation of the Industry 4.0 concept is mainly oriented to industry, in order to maintain or increase competitiveness in the market. Each of the countries compiled has developed its own national strategy to implement the Industry 4.0 concept.

\section{Industry 4.0 concept in the Slovak Republic}

As a result of intensive cooperation between the Ministry of Economy of the Slovak Republic and representatives of industry, the concept of the Intelligent Industry for Slovakia will be formed. The State Concept Industry 4.0 was introduced in 2016 and represents a way for Slovakia to be competitive on a European and global scale. The Slovak concept of the state strategy towards Industry 4.0 is based on the German concept and uses the experience of the Czech Republic and Austria.

The changes that the Intelligent Industry concept brings are mainly addressed to Slovak industrial enterprises, including small and medium-sized enterprises. The content of the concept is to identify the main areas that need to be analysed and then to create an action plan with concrete measures. Areas 
are categorized according to the specificity of the sector, with their common feature being the interconnection of enterprises, industry, state administration, society and education.

The central idea and main task is the transformation of the industry using all the knowledge from the point of view of digitization, internet economy, robotization and interconnection of industry with scientific research institutions and education into a whole capable of existence under Slovak conditions. An important focus of the strategy is to enable companies to provide seamless services across the EU, regardless of where they are based in the EU. The investments made in connection with the new concept will be directed to digital technologies such as various sensors and communication devices, as well as to information systems and software applications. To a large extent, businesses also invest heavily in training their staff, in recruiting new specialists, and in promoting organizational change. One of the tasks of the Intelligent Industry concept is to persuade the public about the necessity of individual steps through recommendations that maintain the position of Slovak enterprises in European and global structures so that they can contribute more to the influence and power in the economy and the functioning of the whole society (GO SR, 2016).

The country encourages the formation and development of enterprises through various incentives in order to reduce regional disparities, especially in less developed regions (Šoltés \& Repková Štofková, 2017).

\section{The Industry 4.0 concept in the Czech Republic}

Following the Industry 4.0 concept, the Czech Republic has developed its own initiative - the National Industry Initiative 4.0 developed by the Ministry of Industry and Trade. The initiative includes information on the necessary changes due to the advent of the Fourth Industrial Revolution (Industry 4.0). In 2016, the Government of the Czech Republic approved an extension of the document on an action plan for the development of the digital market.

The aim of this document is to provide key information related to the theme of the fourth industrial revolution, to show possible changes in development and to propose measures that could not only support the Czech economy and industrial base but also help prepare the whole society for absorbing this technological change.

The individual chapters of the document describe the state of play, the direction of further development and the key challenges in the various areas that need to be addressed in order to increase the Czech Republic's readiness for current developments. The scope and level of material provide detailed information for the Government of the Czech Republic, key sectors and social partners so that they can formulate concrete measures responding to the ongoing changes brought about by the technologies of the Fourth Industrial Revolution (MIT CR, 2018).

\section{Industry 4.0 concept in Germany}

The start of the concept initiative was in Germany, where Siemens and the German government teamed together to create an intensive and targeted promotion of the development of new technology not only for the automation industry but also for all industries under the name Industry 4.0. Subsequently, other European manufacturing companies and countries joined the initiative, creating a phenomenon that ultimately succeeded in unexpectedly intensifying the debate and consequently the interest in using new automation and robotics technology. The Industry 4.0 concept was first introduced at the world's largest technology fair in Hannover in 2013. The industry's original concept of Industry 4.0 was to maintain the competitiveness of industry and to return production from cheap countries back to Europe (Vojáček, 2016).

The Industry 4.0 concept was launched as a "project for the future" as part of the federal government's high-tech strategy as early as 2011, moreover it follows the 2005 Smart Factory research platform. The Industry 4.0 Platform, which brings together trade unions (IT, engineering and electrical engineering) (Volkswagen, Siemens, Infineon, Bosch, etc.), research institutions, the public sector and employers' representatives, was set up in 2013. The platform aims to provide expert advice, industry recommendations and research in key areas of the Industry 4.0 architecture, standardization and standards, research and innovation, system security, legal aspects, education and work aspects.

While large businesses are paying enough attention to the fourth industrial revolution, a substantial part of German SMEs are more cautious. The reason is mainly the fear of high investment costs, new 
technology or endangering intellectual property. Similar distrust can be expected from small and medium-sized enterprises within the Slovak and Czech Republics. For this reason, the Federal Ministry of Economy and Energy initiated the "Go-Digital" program. In particular, the program includes external IT consultancy, from initial analysis to the final implementation of an appropriate IT solution, such as assisting in the implementation of a business IT model, including data protection and cyber security (Podivínský \& Ehler, 2016).

\section{Discussion}

The Industry 4.0 concept deals with the optimization of the entire value chain in product life cycles. This cycle is based on increasing individual customer requirements. It starts with the idea followed by the work, development, production and delivery to the end customer until recycling, including all the services involved. The baseline is the availability of all relevant information in real time (Gbo datacomp, 2018).

Industry 4.0 represents a significant transformation of the entire industrial production through the unification of digital technologies and the Internet with conventional industries (Cotet et al., 2017). The Slovak Republic and the Czech Republic are in the moderate innovators area, unlike the Federal Republic of Germany, which has long been in the Innovation Leadership.

Germany, as compared to Slovakia and the Czech Republic, is not dependent on export and import from other EU Member States. In the year 2016, 66\% of exports to EU Member States were just above the EU average. By contrast, imports from other $28 \mathrm{EU}$ countries accounted for $59 \%$ of total German imports, which are below the EU average (Európske noviny, 2017).

A condition for the economic development of the Slovak Republic is the creation of measures for the implementation of Industry 4.0, which will accelerate the economic development, increase the added value and competitiveness of the Slovak industry and also contribute to higher efficiency in the use of resources. It is important to promote business collaboration with scientific and research organizations, improve the quality of education and graduates of secondary and higher education institutions. It is also necessary to support businesses in their innovation activity (Butek \& Stofkova, 2016). Companies bringing innovative and new ideas that will stand out from the current business environment to the nature of the product, thus be able to quickly be established the international environment (Gregova \& Dengov, 2016).

The described concepts represent a new philosophy of system use, integration and interconnection of the most diverse technologies in maintaining their sustained and very rapid development. Accepting concept-based initiatives is not only a big challenge, but also a new opportunity for industrial companies to work towards making these changes responsive.

\section{Conclusion}

Initial steps for process improvement in an industrial enterprise are to have a strategy, the main purpose to which the business will be directed, and to set processes in a way that best fits them. The necessary step is to automatically collect data, analyse it thoroughly and secure its flow in the company environment and beyond. Every business has its own specifics, differences within one industry, each process is different, each customer's need is different. It follows that every industrial enterprise must find its own way to apply the Industry 4.0 concept.

Industry 4.0 should be seen as an evolutionary process. This process involves innovation and transformation of production, which is interconnected, based on information. Information enables optimization of the company's own production processes as well as the entire value chain. Process optimization is geared towards increasing productivity, innovation activity, and customer care quality. The Industry 4.0 concept philosophy is focused on research and development, standardization and the creation of shared infrastructure for expanding intelligent manufacturing technologies based on advanced data analysis from smart sensors and real-time models and simulations. Ignoring this new reality would lead to a gradual loss of competitiveness not only for individual companies but also for countries.

\section{Acknowledgement}

This contribution was undertaken, as a part of the research project VEGA 1/0755/18. 


\section{References}

The Clever way to find a job. (2017). Industry 4.0: Definition, Design Principles, Challenges, and the Future of Employment. Retrieved from https://www.cleverism.com/industry-4-0/

Gbo datacomp (2018). Gbo datacomp and the trend-setting concept of Industry 4.0. Retrieved from http://www.gbodatacomp.com/company/future-oriented-topics/industry-4-0-has-given-change-a-name

Vachálek, J. et al. (2017). Tvorba digitálneho dvojčat’a výrobnej linky v rámci konceptu Industry 4.0. ATP Journal 124.2017. Retrieved from http://www.atpjournal.sk/rubriky/prehladove-clanky/tvorba-digitalneho-dvojcata-vyrobnej-linky-v-ramcikonceptu-industry-4.0.html?page_id=24830

Balga, B. (2018). Smart factory - inteligentní továrna. IPA Slovakia 28. 03. 2018. Retrieved from https://www.ipaslovakia.sk/sk/tlac-a-media/aktuality/smart-factory-inteligentni-tovarna Industry4.0 insights (2017). Digitalization of Supply Chains and Logistics. Retrieved from https://industry40insights.com/wp-content/uploads/2017/05/Digitalization-of-Supply-Chains-and-Logistics.-Outlook-Survey2017.pdf

Onofrejová, D., Šimšík, D. (2017). Výskumné aktivity zamerané na budovanie platformy pre Priemysel 4.0. ATP Journal 12.4.2017. Retrieved from http://www.atpjournal.sk/rubriky/prehladove-clanky/vyskumne-aktivity-zamerane-nabudovanieplatformy-prepriemysel-4.0.html?page_id=24826

CGI Client Global Insights (2017). Digitalizácia. Retrieved from https://www.cgi.com/en/slovensko/digitalizace

Štofko, S., Šoltés, V., Štofková, Z. (2016). Options of using the integrated management system. In: Production Management and Engineering Sciences - Scientific Publication of ESPM 2015, Pages 267-272.

Čierny, M. (2017). Kvalita a Industry 4.0. IPA, 11. 05. 2017. Retrieved from https://www.ipaslovakia.sk/sk/tlac-amedia/aktualne-vzdelavanie/kvalita-a-industry-4-0

OECD - Organisation for Economic Cooperation and Development. (2005). Oslo Manual: Guidelines for Collecting and Interpreting Innovation Data, 3rd Edition. Retrieved from: http://www.oecd.org/sti/inno/oslomanualguidelines forcollectingandinterpretinginnovationdata3rdedition.htm.

Loucanova, E., Olsiakova, M., Dzian, M. (2017). Open innovation system in business process in the global market. 17th International Scientific Conference Globalization and its Socio-economic Consequences, proceedings, Rajecke Teplice, Slovak Republic pp. $1347-1353$.

Hollanders, H. Es-Sadki, N. (2017). European Innovation Scoreboard 2017. European Commission, 100 p. Retrieved from http://ec.europa.eu/growth/industry/innovation/facts-figures/scoreboards_en

Ministry of Economy of the Slovak Republic (2017). Analýza vývoja priemyselnej výroby, 41 p. Retrieved from http://www.economy.gov.sk/uploads/files/fTxsVEZW.pdf

Ministry of Foreign and European Affairs of the Slovak Republic (2017a). Ekonomická informácia o teritóriu - Česká republika. Retrieved from https://www.mzv.sk/documents/10182/620840/Ceska+republika+-

+ekonomické+informácie+o+teritóriu+2017

Ministry of Foreign and European Affairs of the Slovak Republic (2017b). Ekonomická informácia o teritóriu - Nemecká spolková republika. Retrieved from

https://www.mzv.sk/documents/10182/620840/Nemecko+-+ekonomické+informácie+o+teritóriu+2017

globalEDGE (2017). Germany: Economy. Retrieved from https://globaledge.msu.edu/countries/germany/economy

Európske noviny (2017). Slovensko je podl’a Eurostatu krajinou najviac závislou od vývozu do iných členských štátov. Retrieved from https://europskenoviny.sk/2017/04/07/slovensko-je-podla-eurostatu-krajinou-najviac-zavislou-od-vyvozuinych-clenskych-statov/

Government Office of the Slovak Republic (2016). Rokovanie vlády SR. Retrieved from: http://www.rokovania.sk/File.aspx/ViewDocumentHtml/Mater-Dokum- 204565?prefixFile=m_

Šoltés, V., Repková Štofková, K. (2016). The impact of business environment on regional disparities. In: Innovations in science and education. Prague, Central Bohemia University, pp. 187-191.

Ministry of Industry and Trade of the Czech Republic (2018). Iniciativa Průmysl 4.0. Retrieved from https://www.mpo.cz/assets/dokumenty/53723/64358/658713/priloha001.pdf

Vojáček, A. (2016). Co se skrývá pod výrazy Industry 4.0 / Průmysl 4.0 ? Automatizace.hw.cz 19.3.2016. Retrieved from https://automatizace.hw.cz/mimochodem/co-je-se-skryva-pod-vyrazy-industry-40-prumysl-40.html

Podivínský, T.J., Ehler, T. (2016). Německý fenomén industrie 4.0. Inspirace a př́ležitost pro český průmysl, vědu a výzkum. CzechTrade 22. 2. 2016. Retrieved from https://www.czechtrade.cz/media/czechtrade-media/monitoring/nemecky-fenomenindustrie-4-0

Cotet, G.B., Balgiu, B.A., Zaleschi, V.C. (2017). Assessment procedure for the soft skills requested by Industry 4.0, MATEC Web of Conferences 121, 07005.

Butek, M., Stofkova, Z. (2016). Relocalisation Trends in the Context of Globalization. In: ISSGBM International Conference on Information and Business Management. Hong Kong, Lecture Notes in Management Science, Vol. 61, pp. 33-38.

Gregova, E. and Dengov, V.V. (2016). Startups importance for the successful development of the Slovak economy. In: 16th International Scientific Conference Globalization and its Socio-economic Consequences, proceedings, Rajecke Teplice, Slovak Republic, pp. 505-514. 